\title{
Nina Barszczewska
}

\section{The Role of Writers in the Development of the Belarusian Language in the $19^{\text {th }}-$ Early $20^{\text {th }}$ Century}

Rola pisarzy w rozwoju języka białoruskiego $w X I X$ - początku XXW.

Роля пісьменнікаў у развіциі беларускае мовы у XIX-nачатку XX cm.

\begin{abstract}
Belarusian dialects have become the foundation of the contemporary Belarusian language. The role of two dialects, namely the Southwestern and the Northeastern, was greater or lesser throughout various historical periods. To a great extent, they depended on the place of birth or residence of writers who eagerly used the vocabulary of their native dialect reflecting its phonetic and morphologic features.

In the $19^{\text {th }}$ century, writers enriched the Belarusian vocabulary. However, there were no conditions in the official sphere for Belarusian language to emerge, nor was there a journal published in which the representatives of the Belarusian cultural elite could publish their works that would support the strengthening of general Belarusian features and the development of grammar and spelling norms.

The grammatical-spelling rules of the early $20^{\text {th }}$ century editions, in comparison with the $19^{\text {th }}$ century principles, became more uniform. The randomness and inconsistency of the use of various forms were significantly reduced. It is possible to speak about the existence of certain rules of spelling that appeared as a result of publishing practices, and to which editors of published books and newspapers were faithful. These circumstances contributed to the publishing of a Belarusian Grammar for Schools (1918) by Branislaŭ Taraškievič (codification), which was difficult due to the complexity and variety of the Belarusian dialects. However, the trail has already been cleared.
\end{abstract}

Keywords: Belarusian language, dialects, lexis, codification, writers 


\begin{abstract}
Abstrakt
Białoruskie gwary ludowe stały się podstawą rozwoju współczesnego języka białoruskiego. Rola dwóch dialektów południowo-zachodniego i północno-wschodniego była większa lub mniejsza w różnych okresach historycznych i w dużym stopniu zależała od miejsca urodzenia lub zamieszkania pisarzy, którzy chętnie odwoływali się do zasobów rodzimej gwary, odzwierciedlając zarówno leksykę, jak i jej cechy fonetyczne i morfologiczne. W XIX w. pisarze wzbogacili słownictwo białoruskie, jednak nie stworzono warunków do funkcjonowania języka białoruskiego w sferze oficjalnej, nie założono czasopisma, na którego łamach przedstawiciele białoruskich elit kulturalnych mogliby publikować utwory, co sprzyjałoby umocnieniu się cech ogólnobiałoruskich oraz opracowaniu norm gramatycznych i ortograficznych tego języka. Gramatyczno-ortograficzne zasady wydawnicze z początku XX w. w porównaniu z zasadami XIX-wiecznymi stały się bardziej jednolite; dowolność i niekonsekwencja użycia form znacznie się zmniejszyły. Można nawet mówić o istnieniu pewnych zasad, które pojawiły się jako rezultat praktyki wydawniczej i którym byli wierni redaktorzy publikujący książki i gazety. Stworzyło to dogodne warunki do opracowania Białoruskiej gramatyki dla szkót (1918), kodyfikacji przygotowanej przez Bronisława Taraszkiewicza.
\end{abstract}

Słowa kluczowe: język białoruski, dialekty, słownictwo, kodyfikacja, pisarze

\title{
Анатацыя
}

Беларускія народныя гаворкі сталіся асноваю развіцця сучаснай беларускай мовы. Роля двух дыялектаў - паўднёва-заходняга і паўночна-ўсходняга - была большай альбо меншай у розныя гістарычныя перыяды і ў вялікай ступені залежала ад месца нараджэння ці жыхарства пісьменнікаў, якія ахвотна выкарыстоўвалі рэсурсы роднай гаворкі, адлюстроўваючы яе лексічны склад, фанетычныя і марфалагічныя асаблівасці. Пісьменнікі XIX ст. узбагацілі беларускую лексіку, аднак не стварылі ўмоваў, якія дазволілі б беларускай мове заіснаваць у афіцыйнай сферы, а таксама ім не ўдалося заснаваць такі часопіс, на старонках якога маглі б друкаваць свае творы прадстаўнікі беларускай культурнай эліты, што спрыяла б умацаванню агульнабеларускіх рыс ды станаўленню граматычных і арфаграфічных нормаў. Граматычна-арфаграфічныя прынцыпы выданняў пачатку XX ст. у параўнанні з правіламі з XIX ст. сталі больш аднароднымі, адвольнасць і непаслядоўнасць у выкарыстанні розных формаў значна зменшылася. Можна нават гаварыць пра існаванне пэўных правілаў правапісу, якія склаліся ў выніку выдавецкай практыкі і якіх прытрымліваліся рэдактары выдаваных кніг і газет. Гэта спрыяла апрацаванню Беларускае граматыкі для школ (1918) Браніславам Тарашкевічам (кадыфікацыі), што няпроста было зрабіць з увагі на складанасць і разнароднасць беларускіх гаворак, але шлях ужо быў расчышчаны.

Ключавыя словы: беларуская мова, дыялекты, лексіка, кадыфікацыя, пісьменнікі 
7 he dialects from different regions of Belarus played a big role in the development of the Belarusian language. The participation of the two dialects - the Southwestern and the Northeastern - was greater or less in different historical periods and largely depended on the place of birth or residence of writers, who willingly drew from the lexical resources of the native language, also reflecting its phonetic and morphological features. A characteristic feature of the Belarusian literature of the $19^{\text {th }}$ century was its close connection with local dialects.

The article pertains to the period of formation of the common Belarusian language features in the $19^{\text {th }}$ - early $20^{\text {th }}$ century - before the appearance of the first Belarusian Grammar for Schools by Branislaŭ Taraškievič (1918).

\section{The Belarusian Written Language of the First Half of the $19^{\text {th }}$ Century}

The masterminds behind the renewal of the Belarusian language and the development of Belarusian writing in the first half of the $19^{\text {th }}$ century (Paŭliuk Bahrym, Jan Barščeǔski, Jan Čačot, Aliaksandr Rypinski) originated from different regions of Belarus, so that the most significant features of both dialects appeared in print, which led to their competition and the development of common Belarusian norms (Barszczewska, Jankowiak, 2012, pp. 119-141, 199-220).

Paŭliuk Bahrym originated from the Navahrudak region and in the extant poem Zahraj, zahraj, chtopcze maty ${ }^{1}$ (Play, Play, Little Boy) only two linguistic features are uncharacteristic of this region: the spelling $e$ after the consonants $\varkappa, u(z h, c h)$ at the end of the word (bezdaroże, płacze) and the soft $\mu b$ in the pańszczynu lexeme. This was perhaps due to the fact that the saved version is from 1858, and the verse was written around 1828 . The other features, such as phonetic and morphological, reflected in principle the dialect of Navahrudak and at the same time common Belarusian features such as: non-dissimilar akanne (бацька, карміла); yakanne at the first stressed syllable preceded by unstressed syllable (мяне, ня сей); transition of $л$ into $>\check{y}$, which was transmitted by the $\breve{u}$ grapheme (abuŭsia, szczaśliǔszaja); tsekanne and dzekanne (baćka, maci; hdziez, radziŭsia); stressed $\lrcorner a x$ ending in the prepositional case of masculine and neuter plural nouns ( $u$ maskalax); -bl ending in the nominative case of masculine singular adjectives (biedny, mity); endings of the 3rd person singular of the verbs of I and II conjugations according to the Southwestern dialect and central speeches, which constitute the contemporary literary norm (плачэ, тужыциь) (Blìnava, Mâcel'skaâ, 1980, pp. 95-98); -ui infinitive, as in the Hrodna and Brest dialects, regardless of whether the verb stem ends with a vowel or a consonant (жыціi, тужыці) (Blìnava, Mâcel'skaâ, 1980, pp. 92-93; Kramko, Ûrèvìc, Ânovìč, 1968, pp. 33-34).

Jan Czeczot also originated from the Navahrudak region. He knew the native language well enough to describe and explain its peculiar features. He was also the author

The first texts were written in the Latin alphabet and are rendered here in the original version. 
of the Piosnki wieśniacze znad Niemna i Dźwiny collection as well as a small dictionary. He referred to the Belarusian language as Kryvitsky and he adhered to the basic phonetic principles of the spelling. He saw the need for creating a grammar of the Belarusian language, and even wrote a little in Belarusian. Several of his poems have survived, which reflect such linguistic features of the Navahrudak region as akanne used consistently in stressed syllables preceded by unstressed syllables and optionally in stressed syllables followed by unstressed syllables (czaławiek; naprasna, but dobro, czerwońcou); yakanne used completely but inconsistently (budziam, uspieja, but bieda, ciebie, and even nima, spiwać 'спяваць' / 'singing'); assimilation according to the softness of the consonants, also used inconsistently (jaśniejsza, szczaścia, but cviet, spiewajcie); replacing of the borrowed $\phi$ phoneme by the $n$ phoneme (u praku); lack of prolonging of intervocalic consonants (śmiecie, wiasiela) (Šakun, 1984, pp. 193-196).

His works abound with many features characteristic of various dialects: the $-u_{b}$ or $-u i$ infinitive, regardless of whether the stem of the verb ends with a vowel or consonant (brać, dażyć and harawaci, $\dot{z} y c i)$; indistinguishable endings of the 3rd person of I and II conjugation verbs (niesie, bajeć, zachoczeć) (Kramko, Ûrèvič, Ânovič, 1968, p. 45).

There is also a great influence of the Polish language: the endings of the imperative mood (zbij, pijcie, harujmy); complex forms of the future tense to be + verb in the past tense instead of the infinitive (budzie żau, budziem śpiewali); preposition $\partial a$ instead of $y$ ( $u$ świato da cerkwi chodzić); conjunction нiм (nim haspadynia chatu nahreje); lexemes (chrust, hural, kaleja, pijak, pijany, zausze...) (Kramko, Ûrèvì̌, Ânovič, 1968, pp. 45-46).

Belarusian Northeastern dialects are reflected in the works of Jan Barščeŭski (poems Ach, czym ża twaja dzieweńka hatouka zaniata, Harelica, a fragment of the poem Rabunki mużykou) and Aliaksandr Rypinski (Niaczyścik, ballada białoruska). The following features appear in them: akanne (hatawu, zyta), but used inconsistently (hore, szeptau), dissimilation of endings (pakażyć, choczyc); yakanne (biaz chleba, ciapier), also dissimilated (budzić 'will', dalij); tsekanne and dzekanne (cicha, cho$d z i c$ ); transition of $\pi$ into $>\check{y}$, which both authors record by means of the $u$ graphemes, $-y$ in Cyrillic (byu, hatouka); hard $u$, ж, ч (szeptau, żanat, uczora); hardness / softness opposition in $p / p$ ' in the texts of Barščeǔski (prykażyć and prilacieli), and hard $p$ in the texts of Rypinski (hrech, staryje); assimilative softness of consonants (paraźbiwać, śmiech); verbs of I and II conjugations in the 3rd person singular have the $-u b$ ending, just as in the Northeastern dialect (chodzić, prynosić $i$ biareć, każyć) (Blìnava, Mâcel'skaâ, 1980, pp. 95-98); the -u̧b infinitive as in the Northeastern dialect, regardless of whether the verb stem ends with a vowel or a consonant (ablić, skakać and prynieść, papaść) (Blìnava, Mâcel'skaâ, 1980, pp. 92-93); feminine singular nouns in the nominative case have monosyllabic endings -' $\mathrm{I} \breve{u} /$-ă̌ (smałoj, żonkaj); adjectives in the nominative case singular have the -bŭ / -iü ending (biednyj, druhij).

Despite the fact that Jan Barščeuski and Aliaksandr Rypinski were PolishBelarusian authors, there are few phonetic (krwawy; kietbasa), grammatical (ludzie) and lexical (skrucha, cyna, byle) polonisms in their works, which indicates a conscious differentiation of both language codes (Kramko, Ûrèvič, Ânovič, 1968, pp. 35-40). 
A particularly significant role in the development of the Belarusian language was played by Vincent Dunin-Marcinkievič, whose works drew widely from the Belarusian dialects (in the Pinskaja szlachta comedy, verses and poems). He wrote some poetic works in Polish, and his comedies entitled Sielanka and Zaloty were written partially in Polish, yet some of their characters speak Belarusian. He also published a translation of two books of Pan Tadeusz by Adam Mickiewicz into Belarusian.

As to his Belarusian language, it exhibits features primarily of two groups of dialects, i.e. Babrujsk and Minsk-Maladziečna, which were important in his life. This explains the inconsistency of the language used in his works (Vajtovič, 1958, pp. 1214). There are such features as: akanne - complete (dabradzieju, daloka) and incomplete with the preserved $o$ in the last open syllable when the stress falls on the 3rd syllable from the end (n'aszaho, p'ańskaho), but used inconsistently (cz'ystaha, d'obraha); yakanne - complete, not only in the first stressed syllable preceded by unstressed syllable (biatar'usy, choczacia), although there are often examples with the preserved $e$ (wieczar'oczkam, wiesial' uszka), there is a dissimilar yakanne (dr'obnińkije); the prefixed consonant 8 also occurs inconsistently (woka, u waczach, wulicy, but ab obrazie, nauczau, ulicaju); similarly, the prefixed vowels $a, i$ (ahurkami, ihrajeć, but lizesz, $m c z y c c a$ ); verbs of I and II conjugations in the 3rd person singular appear with endings characteristic of the modern literary language (hlanie, idzie and lubić, uczyć), although there is an -eub ending in the verbs of I conjugation (lijeć, trapieczeć); the $-u b /-u i$ infinitive occurs regardless of the final stem sound, i.e. consonant or vowel (hladzieć, kupić / hulaci, kachaci), but if the stem ends with a $c$, it is always followed by the short form, the typical of the Northeastern dialects (jeść, padnieść); the inverse particle -cя / -cb (napiusia, zalitasia / bajuś, padnialiś); the -bl ending in the nominative case of masculine singular adjectives (czorny, jasny); as well as lexical dialectisms (abałonka, batona 'шыба', asli 'ці', hurmam 'натоўпам', meram 'нібы', suzdrom 'поўнасцю, цалкам’, etc.) (Kramko, Ûrèvìc, Ânovič, 1968, pp. 47-60).

V. Dunin-Marcinkievič made a significant contribution to the processing of phonetic, grammatical and lexical means of the Belarusian language, which drew the attention of later Belarusian authors.

\section{The Written Belarusian Language of the Second Half of the $19^{\text {th }}$ Century}

The socio-political situation of the second half of the $19^{\text {th }}$ century influenced the development of other written genres. The most intensive development was observed in journalism, the vivid example of which is Mużyckaja Prauda, published in the Latin alphabet in $1862-1863$ and edited mainly by Kastuś Kalinoŭski - only the $7^{\text {th }}$ issue of the newspaper is completely different from the previous ones. The language of the six issues of Mużyckaja Prauda and Letters Under the Gallow by K. Kalinoŭski corresponds to the Hrodna dialects. 
The following features appear in them: akanne, which is variously realized in stressed syllables preceded by unstressed syllables and stressed syllables followed by unstressed syllables - it appears before the word stress in 94.8\% (addaci, Kaściuszku, Maskale, padatki, sakiery and swoju, zlitowania), after hissing consonants and $p$, dominated by lexemes with preserved $e$ (czeho, piereprosisz), but an $a$ appears sporadically as well (czalawiekowi, zaprahaje); in the last stressed syllable followed by an unstressed syllable $o$ is preserved (aszukaństwo, Jaśko, widno), but in the $7^{\text {th }}$ issue of the newspaper okanne prevails in 99\% (bohatyi, pobor, oddać), with akanne in the remaining $1 \%$ of cases (adzin, hramada, polskamu); yakanne, which appears in Mużyckaja Prauda sporadically (dziaciuki mixed with dzieciuki, dziarżem sia) and much more often in letters, where the forms of yakanne in comparison with the forms of yekanne appear in the 2:1 ratio (biaz sudu, ciapier, jana, siabie, wajawaci / jeny, niechaj, pierojdzie); tsekanne and dzekanne (dalacieta, dziwowaci sia); lack of consonant prolonging in the intervocalic position (poustanie, sumlenie); the replacement of the $f$ phoneme with the $n, x_{b}$ phonemes (Prancuz, manichwest); the - $u_{b} /-u i$ infinitive if the stem ends with a vowel (hawaryć, hlumić and pałazyci, rabici), only in the $7^{\text {th }}$ issue of Muzyckaja Prauda there are verb forms in which a labial consonant is followed by a $b l>y$ transition (adbuwali, nie buło); the verb of the I conjugation in the 3rd person singular with the $-u b$ ending, optionally using forms without a -ub (budzić / budzie); personal forms of reflexive verbs with the -cb postfix (dobiliś, ktanialiś) (Omeljaniuk, 1989a, vol. 18, pp. 201-208; Omeljaniuk, 1989b, vol. 15, pp. 101-109).

Interesting results are obtained by comparing the language of Muzyckaja Prauda and Letters Under the Gallow with the dialect of the Mastavlyany village, where $\mathrm{K}$. Kalinoǔski was born. It also exhibits a similar linguistic randomness. This is an additional argument which indicates that K. Kalinoŭski was the author or editor of Mużyckaja Prauda (No. 1-6), considering the changes that have occurred in the dialect for more than 150 years since the first publication of the newspaper (Omeljaniuk, 1989a, vol. 18, p. 208).

After the uprising of 1863, a period of social and political pressure began in the Belarusian lands. In response to the national liberation movement, the tsarist government launched actions aimed at a rapid russification of the Northwestern region. Printing in the Belarusian language was interdicted. It was only possible to publish folklore materials or historical documents, while the import of Belarusian books published abroad was also prohibited. The Belarusian language was ousted from the educational process (Šakun, 1984, pp. 208-209).

The revival of the Belarusian literature began only in the late 80 s and early 90 s of the $19^{\text {th }}$ century, along with the rise of the revolutionary movement in Russia. The works of Belarusian writers began to appear in print even abroad - there were separate collections of poems (Dudka bietaruskaja and Smyk bietaruski by Francišak Bahuševič, Wiazanka by Janka Lučyna, Aliaksandr Jeĺski's translation of the first part of Pan Tadeusz). Along with the development of the Belarusian literature, the Belarusian language developed, enriched with new lexical and stylistic means. Grammar and 
spelling norms became more homogeneous, despite the fact that the authors continued to refer to different Belarusian dialects.

All the time there was a great influence of two neighboring languages: Russian and Polish. At that time, Russian was the only official language in the Belarusian lands. Moreover, addition, it came from the transitional Belarusian-Russian dialects, as well as thanks to the increasingly frequent translations of Russian literature. The Polish language, in turn, continued to be the language of the creative works of Belarusian writers of the second half of the $19^{\text {th }}$ century who were bilingual, as were their predecessors. This influenced their interest in translating works of Polish literature. The Polish lexicon reached the Belarusian language not only by means of books, but, first of all, thanks to their close neighbourship. Belarusians and Poles lived together on those lands, which contributed to the penetration of some elements of the Polish language into the Belarusian dialects, and from the dialects - into literary works.

In the difficult conditions of the period, there were attempts to create a grammar of the Belarusian language. Paviel Špilieŭski in 1846, and Ksaviery Niadzviedzki in 1854 handed in the manuscripts of grammars to the appropriate scientific institutions, but they ended up in the archives. More recent works, for example the one by Jaŭchim Karski, focused only on national dialects and did not include the literary language norms (Šakun, 1984, pp. 211-214).

As to spelling, it was always considered to be rather arbitrary. This issue was noticed by Belarusian writers, who discussed it in order to develop some common standards, but it was still not clear which of the dialects would have a greater impact on the normalisation of the Belarusian language. In this regard, no one desired to yield and no longer promote their native speech, as evidenced by the statement of Allhierd Abuchovič found on the pages of the Homan magazine (No. 37, Vilnius 1916): У каниь невядома яшчэ, каторы дыялект беларускі пераможа² (Šakun, 1984, pp. 214-215).

In principle, all $19^{\text {th }}$-century works printed in Latin Polish version triggered a more acute reaction of the tsarist authorities, who did not wish to allow for a rise in the Polish influence in the Northwestern region. Due to the frequent repressions, there were attempts to record the Belarusian texts with the help of Russian graphemes, which was the reason for the introduction of several features unusual for Belarusian dialects, such as: the preservation of яць (дзътки), okanne (кобьла, пошли), the preservation of soft m', д' (день, чувать), soft p' (грешньл, пригоднь), soft hissing consonants (нашей, яще), short or non-syllabic $\breve{y}$ reproduced with the help of the the $в$ or $y$ graphemes (прижов, прауда), etc. (Šakun, 1984, pp. 215-217).

A person who played a very significant role was Francišak Bahuševič, quoted to this day about the role of the native language in the life of every nation as his warning Nia pakidajcież naszaj mowy biełaruskaj, kab nia ŭmiorli! ${ }^{3}$ (Buraczok ${ }^{4}, 1891$, p. V) is

\footnotetext{
'In the end, it is still unknown which Belarusian dialect will win'

'Don't renounce our Belarusian language or we will die!'

4 Maciej Buraczok - a pseudonym of Francišak Bahuševič.
} 
still relevant. Bahuševič wrote that the language was the garment of the soul, thanks to which a nation was recognised and distinguished from others: Paznajuć ludziej ci pa havorce ci pa adieży, chto jakuju nosie; otoż haworka, jazyk i jość adieża duszy (Buraczok, 1891, p. V). The language of his works, written in Latin alphabet, is characterised by: akanne in all stressed syllables preceded by unstressed syllables and in most stressed syllables followed by unstressed syllables (адпусьціиь, каханак); preservation of an etymological $o$ in the last open syllable (incomplete akanne, as in the Southwestern dialect), but only when the stress falls on the third syllable from the end (ciomnaho, dobraho), since if it falls on the second syllable from the end, then in the ending akanne is observed (krywoha, maloha); saving $e$ after $ж, u, u, p, u$ (każe, pisze, ihryszcze, hawore, serce); dissimilar akanne in verbs (możysz, choczym); inconsistent reflection of akanne in the stressed syllables preceded by an unstressed syllable and also in stressed syllables followed by unstressed syllables (biadawać, wiaciarok, alejam, drukowanyja, but jeszcze, nowyje); dissimilar yakanne in verbs (hlanisz, aziraitca); lack of consonant prolongation in the intervocalic position (kazanie, nasienie); tsekanne and dzekanne (ab życi, ździek); transition of $\pi$ into > $\check{y}$ (doŭh, dzieŭka); the presence of $\partial \varkappa<* d j$ affricates (dożdzyk, hladizu); inconsistent assimilative softening of consonants (ćmiana, haścinczyk / adpuscili, dzwiery); greater randomness in the use of the prefixed consonants: 2 (harech, zaharaŭsia), в (woka, wokruh), forms without prefixed consonants (uszy, u opratce); differentiation of the $-y /-a$ endings in the genitive case of masculine singular nouns according to the later literary norm (smutku, żalu; bileta, katta); ending -bl in the nominative case of masculine singular adjectives (ciomny, wysoki); monosyllabic ending $\lrcorner$ oŭ / -aŭ in the genitive and instrumental case of nouns, adjectives and pronouns of the feminine singular (mowy biełaruskaj; mowaj czyściusińkaj, kasoj); the differentiation of the endings -ub / -uıi in the infinitive depending on the ending of the base by a vowel or a consonant (chadzić, czytać; leźci, prapaści); verb forms of the 3rd person singular and plural typical of the Northeastern dialect, where there is no distinction between verbs of the I and II conjugations (trapie, zrobie / rawieć, żywieć; czytajuć, stralajuć / haworuć, leczuć); lexical dialectisms (niemaraść 'impure force, dream', prywarak 'boiled food', prytyka 'wooden pole for fixing the net on fish'); lexical polonisms (dziś, kalejka, ksionzka, prandzej) (Kramko, Ûrèvič, Ânovič, 1968, pp. 89-95).

Bahuševič's respect for the language was manifested not only in the role of the language in the life of every nation, but also in the approach to the language itself, which was the main source of the search for new lexemes, phraseological units, proverbs and sayings. Careful analysis of the dialect material brought a good result, and therefore his works contain few linguistic features which did not eventually become a literary norm. Among other things, these are the verb forms of the 3rd person singular and plural, typical of the Northeastern dialect, where there is no distinction of the verbs

\footnotetext{
5 'You learn about people by the way they speak or they clothes, who wears what; and conversation or language is the garment of the soul'
} 
of the I and II conjugations (trapie, zrobie and rawieć, żywieć); syntax constructions, which appeared due to the non-differentiation of the category of animate - inanimate objects (koni pakrali, trapiŭ nie ŭ ptuszki, bjeć u zwona); lack of consonant prolongation in the intervocalic position (biezdaroże, stwarenie); prefixed 2 , as in the part of Hrodna and Brest dialects (harech, zaharaŭsia) (Blìnava, Mâcel'skaâ, 1980, pp. 5859; Čarnâkevič, 2009, maps 41-48); stress often corresponding to the norms of the Polish language, falling on the penultimate syllable (asesoram, dukatami, radosci, sirota) (Šakun, 1984, p. 225).

In the $19^{\text {th }}$ century, the Belarusian language was enriched with new vocabulary items, but there necessary conditions that would allow the Belarusian language to exist in the official sphere had not been provided. It was also impossible to found a magazine where the representatives of the Belarusian cultural elite could print their works. This would help to reinforce the characteristic Belarusian features and form grammatical and spelling norms.

\section{The Belarusian Written Language of the Early 20th Century}

At the beginning of the $20^{\text {th }}$ century, the national liberation movement intensified its activity in the Russian Empire, which forced the tsarist authorities to reach some compromise. The Act on Freedom of the Press, which allowed for publications in the Belarusian language, was issued on 24 November 1905. Tsarism, however, did not abandon the dream of national expansion. Works which had already been published were confiscated, including a collection of poems entitled Жалейка / Zhaleyka by Janka Kupala, or selected issues of the Naša Dolia (four out of six issues) and Naša Niva newspapers. Belarusian language, like Ukrainian, was not allowed in various spheres of social, cultural and political life, unlike the languages of other nations: Poles, Lithuanians, Germans, Tatars, Estonians, Latvians, Armenians, Czechs, Georgians, Buryats, Kalmyks and Jews, who were allowed education in their native language in 1910 by the State Duma. Nevertheless, the first Belarusian language publishing houses began to appear. These were Загляне сонцэ і у нашэ ваконцэ ${ }^{6}$ in St. Petersburg (1906), which published the Naša Dolia (1906) and Naša Niva (1906-1915) newspapers, the first textbooks Беларускі лемэнтар, або Першая навука чытання aniec (1906), Першае чытанне для дзетак беларусай ${ }^{8}$ by Ciotka (1906), Другое чвлтанне для дзетак беларусайу by Jakub Kolas (1910). They published literary and social periodicals, such as Маладая Беларусь ${ }^{10}$ (1912-1913) and other magazines:

\footnotetext{
'The sun will be shining in our window'

'Belarusian primer or The First Study of Reading'

'The First Book of Reading for the Children of the Belarusians'

9 'The Second Book for Reading for the Children of the Belarusians'

10 'Young Belarus'
} 
agrarian Caxa / Sacha ${ }^{11}$ (Vilnius-Minsk 1912-1915), magazines for children Лучынка / Lučynka ${ }^{12}$ (Minsk 1913-1914), a religious weekly Беларус / Belarus (Vilnius 19131915), the satirical Крапіва / Krapiva ${ }^{13}$ (Vilnius 1913), a student magazine Раніца / Ranica ${ }^{14}$ (St. Petersburg 1914), as well as socio-political and literary newspapers: Гоман / Hoтаn (Vilnius 1916-1917), Дзянніца / Dziannica (St. Petersburg 1916), and Cветач / Svietač (St. Petersburg 1916). There were also new publishing houses: Наша Хата / Naša Chata, Мiнчук / Minčuk, Беларускае выдавецкае таварыства ${ }^{15}$, Palačanin, and A. Hrynievič's publishing house. Meanwhile, Belarusian bookshops opened in Vilnius, Minsk and Polack (Šakun, 1984, pp. 234-237).

Naša Niva played a special role, assembling the Belarusian national elite from different parts of the country. It contributed to the development of the literary language norms in terms of spelling, grammatical rules and lexical resources. As the language of Naša Niva and of the books printed in the publishing house Загляне сонцэ і у нашэ ваконцэ ${ }^{16}$, so as the language the first textbooks in Belarusian language (printed both in Latin and Cyrillic alphabets) reflected the following features of Belarusianness: non-dissimilar akanne (абавязак, вада, горад); incomplete akanne with the preserved $o$ in the last open syllable (as in the Southwestern dialect), but only when the third syllable from the end was stressed, or when the second syllable was stressed, there was a complete akanne (жывога народного духа), optional spelling of o/a in unstressed noun endings (права / право, жыта / жыто), verbs (пахла / пахло, згарэла / згарэло); o preserved in the -то particle (ияпер-то, нібы-то); unstressed $o$ left in the borrowed vocabulary and proper names (ботаніка, ортопэдычны; Копэрнік, у Орэнбурзе), when the borrowings took root in the Belarusian lexicon, they followed the rules of akannye (мадэрніст, палітыка); $e$ was left unstressed following $u, ж, 4$, $u$ and $p$ (грошэй, можээ, вечэр, сэриэ, перэбіраючы); yakanne in the first stressed syllable preceded by unstressed syllable (бяз глебы / без народу, не магла ня кінуцча), when $a$ is not stressed (зямлі / земля); $е$ preserved in the stressed syllables followed by an unstressed syllable (вылет, краем, родные); also in the borrowed vocabulary (тэлефон, электрычны); there were deviations in the direction of full yakanne, characteristic of the dialects of the Hrodna region, most of the Minsk region, and the Eastern districts of the Homiel region (сёлята, веияя) (Blìnava, Mâcel'skaâ, 1980, p. 36, DABM, maps 8-14), or dissimilation typical of the Northeastern dialect (сідзяиь, uіંжар) (Blìnava, Mâcel'skaâ, 1980, p. 33-35); optional spelling of the stressed э and $a$ after ж, $\varphi$ in the verb endings (Міхалка задрыжэў / пан задрыжай, галда крычэла / Тамаш крычаў), as in the Northeastern and Southwestern dialects (Avanesaŭ, Atrahovič, Mackevič, 1968, pp. 186-185); random spelling of the ія /ьıя combinations,

\footnotetext{
11 'Plough'

12 'Splinter'

13 'Nettle'

14 'Morning'

15 'Belarusian Publishing Association'

16 'The sun will be shining in our window'
} 
as in the contemporary lexemes бібліятэка, матэрыял оr бібліотэка, матэр'ял, nатрыот; reinforced hard $p$ (курыць, на рэку); alternations between $2-3^{\prime}, x-c^{\prime}, \kappa-u$ before the front vowels (дарога - па дарозе, верх - на версе, Афрыкка - у Афрыцы); $\pi, 6$ transition following vowels in $\check{y}(в о \check{у к, ~ к р ы у ~} \check{\partial} a$ ), although there are examples that do not correspond to this rule (сваім улласным and была у яго); in the borrowed names, there was a tendency to preserve the 6 , but it was implemented inconsistently (Владыслай, Марков, Некрасоў, Уладзімір); prolonged consonants in the intervocalic position (галлё, Залессе), as in the dialects of Viciebsk, Polack, Minsk, the Northeastern part of the Homiel region and the Southeastern part of the Brest region (Blìnava, Mâcel'skaâ, 1980, pp. 55-56); prefixal consonant 8 before $o, y$ (вобыск, вураднік) and prefixal vowels $a, i$ before consonant combinations (аржаны, імчаусся); tsekanne and dzekanne before front vowels and the consonant в' (дзеля пацехі альбо цікавасьиі, у голадзе) as well as the preservation of hard $m, \partial$ in the borrowed vocabulary items (тэатр; дэмакрат, у мэдыцыниі); preservation of soft $л^{\prime}$ in the loan words (калёнія, клясычны, парлямэнт); inconsistent reflection of assimilative consonant softness (прайсьиі / прайсиіся, роўнасьиі / роўнасиі); lack of consonant assimilation between morphemes and at the end of a word (абпаленьлх, бязспорна, гразь); the following phonetic principle at the combination of consonants: $\partial+$ ств $>$ дзтв (сьледзтва), $u+$

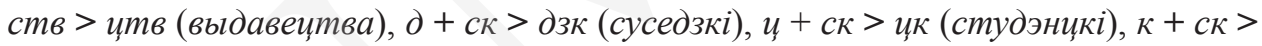
ик (настайніикі), $ч+c \kappa>$ ик (рубяжээвіцкі), з $+c \kappa>c \kappa$ (франиускі), assimilation of the inverse particle -ся (застаица) and the transition of $\partial u>u u$ in numerals

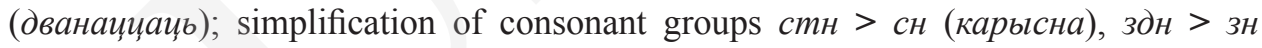
(позна); spelling of -ія following $u$ in loan words, non-relevant to the Belarusian pronunciation (нація, рэакиія), evidently influenced by the Russian tradition, although there was also a sporadical variation of the -бъя (рэвалюцыя) spelling which was relevant to the Belarusian pronunciation; -bl ending in the nominative case of neuter plural nouns, as in the Northeastern dialect (рэбры, словы); as in the Southwestern dialect, to the South-West of the line Ašmiany - Maladziečna - Minsk - Mar'ina Horka - Babrujsk - Svietlahorsk - Chojniki - Kamaryn, there is the old - $a$ ending (иялята) (Blìnava, Mâcel'skaâ, 1980, pp. 73-74); after soft consonants, the $-r$ ending dominates, as in the Southwestern dialect (новыя адкрыцьия, свае вучэньня), the - $i$ ending, typical of the Northeastern dialect is less frequent (ваенные змаганьні); the $-i /-e$ endings in the prepositional case of singular nouns (на дарозі, у магілі; на сенакосе, у пчальніитве): $-i$ prevails on a large area in the Northeastern dialect as well as in the Southwestern dialect, but $-e$ is found more often in the Central dialects, in territory from Babrujsk to Vilnius (Kramko, Ûrèvìč, Ânovič, 1968, p. 127); parallel use of the Northeastern monosyllabic ending 」ой / -ай (абеияанай землёй, верхняй Віслай) and the Southwestern two-part ending $\lrcorner$ ою / -аю (пад зямлёю, сваею доляю) in the nominative case of singular nouns, adjectives and feminine pronouns; $\lrcorner_{O M} /-a M$ endings in the instrumental case of singular masculine nouns (з узелком; быу сьведкам, выбралі дэпутатам); sporadic use of -ом / -эм as a result of the inconsistent reflection of akanne (гэтакім парадком, сваім розумом; прагрэтае сониэм); -ог̆/-аў endings in the genitive plural 
of the nouns with a soft stem of the masculine and neuter gender: -oy both in the stressed (нажоў, рамянёу) and unstressed position, which is caused by the labialisation

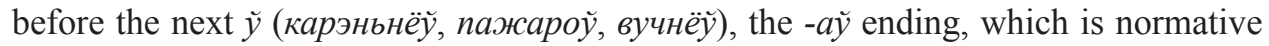
today, was also used quite often (беларусай, вучняў); zero ending and -ац̆ (-оў) in the genitive case of plural feminine nouns with the stress on the word stem (думак, сосан; расьлінаў, тыссячоў): zero ending appears in the Central Belarus, in the West and North-West, whereas $a \check{y}$ (-oy) in the territory of the Central Belarus, predominantly in the East and South; the distinction between stressed and unstressed - ${ }^{\mathrm{I}}$ oм / - - $а \mathrm{M}$ endings in the dative case of the masculine and neuter plural nouns and $\lrcorner_{o x} /-a x$ in the prepositional case (братом беларусам; па краёх / на сэймах), typical of the Central Belarusian dialects; the $-b l /-i$ endings in the nominative case of singular masculine adjectives, peculiar to the whole of Belarus (высскі сухі груд, жызвы набытак) with the exception of the outskirts of the North-East and South-West, where the -biŭ / -iŭ endings are used (польскій пасад, especially in participles - статут выданый, замёрзшый); monosyllabic ending -ой, and disyllabic -oe in the genitive case of singular adjectives, pronouns and ordinal numbers (намай справы, роднае мовы), monosyllabic ending is used in the Northeastern dialect, while the disyllabic one in the Southwestern dialect; the lack of distinction between the verb endings of the 3rd person singular depending on the conjugation (I conjugation - раскажэ and выглядаіиь; II conjugation - поіць and малоие), this situation is typical of dialects transitioning from the South-West to the North-East; - eм / -ёM, -iм endings in the 1st person plural of indicative mood (выйдзем, ідзём, робім) and, more rarely, -емо, -імо (паедземо, просімо); the -ыце / -іце (насіие, плаиіие), -еце(я) (адчынеия, пакажэия) endings in the imperative verbs of the $2 \mathrm{nd}$ person plural, derived from both dialects: isoglosses of the -blue / -iuge forms are found along the lines of: Voranava - Iŭje - Ivianiec - Dziaržynsk - Mar'ina Horka - Babrujsk - Kapatkievičy - Lieĺčycy (Blìnava, Mâcel'skaâ, 1980, pp. 100-101; DABM, map 170); in verbs, gerunds and verbal nouns, the -blвa suffix was consistently used, typical of the Northeastern dialects (абкідываюиь, перэдруковываючы, размножываньне); contemporary literary forms with the -ва suffix (the Southwestern dialect) were sporadic (прачытвала, выслухоўвалі); - иь forms in the infinitives with a stem ending with a vowel (жыць, працаваць), -иi in those ending with a consonant (iсьиi, сесьиi), and $-4 b l$ in those ending with a velar (змусілі уияячь); sporadic deviations from this rule have survived to this day (упасьць).

It should be noted that the grammatical and orthographic principles of the language variations of the beginning of the $20^{\text {th }}$ century are more homogeneous and reflect the features of the Belarusian language better. They contain fewer cases of arbitrariness and inconsistency in the use of different forms. It is even possible to speak about the existence of certain spelling rules which appeared as a result of the publishing practice, to which the editors of the published books and newspapers adhered (Šakun, 1984, p. 240).

The lexical resources of the Belarusian language were enriched at the expense of Belarusian dialects. These provided the well-known lexemes, although a narrow 
regional lexicon was also used from time to time. However, the borrowed vocabulary items were often translated into Belarusian, leading to the usage of duplicates defining the same designatum or concept (біяграфія - жыцьияпісаньне; дэманстраваны паказываны; крэдыт-пазычка). A striking example of this trend is the appearance of the names of the Belarusian months. In 1907-1909, Naša Niva used the январ and стычань lexemes for January; from 1910, it was студзень. This also concerns other Belarusian names of months: сакавік, красавік, травень, чэрвень, ліпень (from 1908) жнівень, верасень, кастрычнік, лістапад, сьнежань; from 1912, these names were used together with Latin and Polish, and from 1912 - Belarusian names were consistently applied (Ostrowski, 2011, pp. 109-129).

The existing gaps were filled in various ways: by creating neologisms (цягнік, вылдатны, зносіны); by tracing words, primarily from the Russian (большасьиь, міжнародныл, узрост) and Polish language (адналіты, супрацоунік, выдавецтва), and even both languages at the same time (дастойнасьиь < достоинство and godność, прывітаньне < приветствие and powitanie); borrowings from other languages, mainly from Russian (адстайка, дакладчык, кровапраліиьце) and Polish (выбітны, гарбата, мэбля) or their mediation (Kramko, Ûrèvìc, Ânovič, 1968, pp. 137-154).

The process of formation of all-Belarusian language features in the early $20^{\text {th }}$ century and the participation of individual dialects in it was determined by the editors of Naša Niva and the first publishers, as well as the best writers, originally from Minsk and its surroundings or Vilnius and neighboring areas (Ašmiany, Viliejka, Valožyn). The most significant dialects were the Viliejka and Barysau dialects. This also resulted from the literary tradition - the representatives of the borderlands of two Belarusian dialects were Vincent Dunin-Marcinkievič and Francišak Bahuševič, whose works were issued before the appearance of Naša Niva and at the time of nashaniuski. The younger generation, raised by Naša Niva, followed the established tradition. The principles and norms that emerged during this period were also adhered to by the later publishing houses, founded after the closure of Our Field (Kramko, Ûrèvič, Ânovič, 1968, pp. 153-154).

Janka Kupala and Jakub Kolas played a huge role in the development of the Belarusian language. They enriched the language of Belarusian literature, defining the directions of its development and boldly drawing lexical means from dialects. Dialectisms in their works can be divided into several groups: lexical, ethnographic, lexico-ethnographic, and semantic. Among the lexical dialectisms, it is possible to distinguish the following: actually lexical (аруд - lit. засек, асьвер - lit. журавель, рылтва - lit. калдобіна), derivational (зірк - lit. позірк, пастыр - lit. пастух, тоншу - lit. танчэйшы), grammatical (царызма fem. - lit. царыззм male, 3 person, singular; даець - lit. даe, 3 person, plural; точуиь - lit. точаць, 1 person, plural; пажнямо lit. пажнем) and phonetic (карыдор - lit. калідор, спокваля - lit. спакваля, хронт lit. фронт, хвартух - lit. фартух). Ethnographic dialectisms have no lexical equivalents in the literary language. They are connected mainly with the life of the person with 
a spiritual and material culture (груца 'barley porridge', жычка 'red ribbon'). In one of their meanings, lexico-ethnographic dialectisms have equivalents in the literary language, while in their second meaning, they are considered ethnographic (пяколак - 1 . lit. прыпечак, 2. 'a warm place on the stove where you can warm up', 3. 'niche in the oven, stove'). Semantic dialectisms constitute meaningful lexemes which in are used today in their literary aspect in one of their meanings, and as dialectical in the other (даўжнік - lit. debtor, dial. - джала) (Omeljaniuk, 1990, pp. 257-265; Omeljaniuk, 1992, pp. 85-97; Omeljaniuk, 1995, pp. 39-46).

Taking into account the period in which both classics of the Belarusian literature wrote, it can be argued that they consciously introduced dialecticisms into the Belarusian language. Firstly, the Belarusian language was not normalised yet and its vocabulary was not very rich. Secondly, their work was addressed at the reader from the masses. Thirdly, in the later period, when the process of normalisation began, literary norms allowed for inflection variations. It should also be taken into account that some morphological features, which are now perceived as dialect features, were presented as literary standards in the grammars of the 1920s. Dialectisms are used as synonyms of common Belarusian lexemes or as names of some designations and concepts that have no equivalents in the literary language. This last group of dialectisms particularly enriches the language. Lexical dialectisms, in turn, develop the intra-linguistic synonymy. This is a useful process, provided, however, that it concerns not narrowly regional lexemes but the lexemes characteristic of the vast territory of Belarus (Barščèǔskaâ, 2011, pp. 233-244).

In the works of Belarusian literature classics, polonisms have also been encountered. Mostly of lexical nature, they can be found, for example, in the language of Jakub Kolas (хэнщь, енк, скрыдль, цеенгле, нагле). In later editions, the author replaced some of them with Belarusian lexemes (няма хэниі працаваць - няма сіль прачаващь, енк балючай душы - стогн балючай душы, каб меў скрыдлы палящеу бы - каб меў крылле паляцеў бы). Polonisms in the work of this writer may be divided into individual (агон - спадніцай вериіць як агонам, гавэнда - марная гавэнда and дарэмны крыкк) and common language items that have taken root in the Belarusian language and are found in the literary language dictionaries (галган, модль, пашэниіиь). Among polonisms, there is a separate group of phraseological units. For instance, the Polish phraseologism spuścić nos na kwinte appears in the works by Jakub Kolas in two variants (спускаиь нос на квінту and вешаиь нос на квінту ${ }^{17}$, miеć тисhy w nоsie (мух немала меуу у носе ${ }^{18}$ ). Polonisms have been skillfully applied to characterize individuals or environments (Timoszuk, 1990, pp. 249-256).

Significant changes in the approach to the Belarusian language ensued following the Russian revolution of 1917. Eventually, it became clear that the Middle Belarusian dialect group plays the greatest role in language development (especially in the Central

\footnotetext{
17 'to lower the nose to the fifth and hang the nose to the fifth'

18 'had some flies in the nose'
}

Studia Białorutenistyczne 13/2019 
areas of the Minsk region and partially the Eastern districts of the Hrodna region), and they should be the source of material for those who strive to normalise the Belarusian language. Under the influence of these dialects, even before 1917, such features were establiahed in the Belarusian press as non-dissimilar full akanne, hard consonants $ж$, $u, u, p, u$ and hard labial consonants before $\breve{u}$ and at the end of the word, alternation of the stressed $р о, л о$ with unstressed $p b l, \pi b l$, fricative 2 and full forms of the adjective in the predicative function (Kramko, Ûrèvič, Ânovič, 1968, pp. 274-275).

An important date in the process of normalisation of the Belarusian language was 1918, when such important works were published as Беларускі правапіс ${ }^{19}$ (Vilnius) - it was, in principle, a reproduction of the booklet published in 1917, entitled Як правільна пісаџь па-беларуску, Просты спосаб стациа у кароткім часе граматным ${ }^{20}$ (1918) and, of course, Беларуская граматыка для школ ${ }^{21}$ by Branislaŭ Taraškievič (Vilnius), which had to wait five editions before being published (with the last one, corrected and significantly expanded, published in 1929). For a long time, Taraškievič's Grammar was the only textbook serving as a basis for new didactic and scientific works in the Belarusian language. The author processed the spelling, grammatical and syntactic rules of the Belarusian language, which was not an easy task to do, taking into consideration the complexity and diversity of Belarusian dialects. Yet the path had already been cleared by Belarusian writers, editors and publishers of the $19^{\text {th }}$ - early $20^{\text {th }}$ century. They used lexical resources of native dialects, also reflecting the phonetic and morphological language features. Their purpose was to develop homogeneous language norms and thereby limit the number of inconsistencies in the use of various grammatical forms.

Translated into English by Marharyta Svirydava

\section{References}

Avanesaŭ, Rubèn (ed.). (1963). DABM - Dyâlektalagičny atlas belaruskaj movy. Mìnsk: Vydavectva Akadèmìi navuk BSSR. [Аванесаў, Рубэн (ed.). (1963). ДАБМ Дыялекталагічны атлас беларускай мовы. Мінск: Выдавецтва Акадэміі Навук БССР].

Avanesaŭ, Rubèn; Atrahovič, Kandrat; Mackevič, Ûzèfa (ed.). (1968). Lingvistyčnaâ geagrafiâ i grupoǔka belaruskih gavorak. Mìnsk: Navuka ì tèhnìka. [Аванесаў, Рубэн, Атраховіч, Кандрат, Мацкевіч, Юзэфа (ед.). (1968). Лінгвістыцная геаграфія і групоўка беларускіх гаворак. Мінск: Навука і тэхніка].

19 'Belarusian Spelling'

20 'How to Write in Belarusian, a Simple Way to Become Literate in a Short Time'

21 'The Belarusian Grammar for Schools' 
Barščèǔskaâ, Nìna. (2011). Dyâlektyzmy ǔ move Ânkì Kupaly ì Âkuba Kolasa. Annus Albaruthenicus, 12, pp. 233-244. [Баршчэўская, Ніна. (2011). Дыялектызмы ў мове Янкі Купалы і Якуба Коласа. Annus Albaruthenicus, 12, pp. 233-244].

Barszczewska, Nina; Jankowiak, Mirosław. (2012). Dialektologia białoruska. Warszawa: Slawistyczny Ośrodek Wydawniczy (SOW).

Blìnava, Ėvelìna; Mâcel'skaâ, Eǔdakiâ. (1980). Belaruskaâ dyâlektalogîa. Mìnsk: Vašèjšaâ škola.

[Блінава, Эвеліна; Мяцельская, Еўдакія. (1980). Беларуская дыялекталогія. Мінск: Вашэйшая школа].

Buraczok, Maciej. (1891). Dudka białaruskaja. Kraków: Wydawnictwo W.L. Anczyc i S-ka.

Čarnâkevič, Ûryj. (2009). Atlas gavorak paǔnočna-ǔshodnâj Brèstčyny. Minsk: Tèhnalogiâ.

[Чарнякевіч, Юрый. (2009). Атлас гаворак паўночна-ўсходняй Брэстчыныл. Мінск: Тэхналогія].

Kramko, İvan; Ûrèvič, Alena; Ânovič, Alena. (1968). Gistoryâ belaruskaj litaraturnaj movy. Vol. 2. Mìnsk: Navuka ì tèhnika. [Крамко, Іван; Юрэвіч, Алена; Яновіч, Алена. (1968). Гісторыя беларускай літаратурнай мовыл. Т. 2. Minsk: Навука і тэхніка].

Omeljaniuk, Nina. (1989a). Jeszcze o autorstwie „Mużyckiej Praudy” i listów ,z-pad szybienicy”. Studia z Filologii Rosyjskiej i Stowiańskiej, 18, pp. 201-208.

Omeljaniuk, Nina. (1989b). Wersje językowe gazety „Mużycka Prauda”. Studia z Filologii Rosyjskiej i Stowiańskiej, 15, pp. 101-109.

Omeljaniuk, Nina. (1990). O dialektyzmach w języku Janki Kupały. Studia z Filologii Rosyjskiej i Stowiańskiej, 13, pp. 257-265.

Omeljaniuk, Nina. (1992). O dialektyzmach w języku Jakuba Kołasa. Studia z Filologii Rosyjskiej i Stowiańskiej, 21, pp. 85-97.

Omeljaniuk, Nina. (1995). O dialektyzmach w białoruskim języku literackim. Studia z Filologii Rosyjskiej i Słowiańskiej, 22, pp. 39-46.

Ostrowski, Bogumił. (2011). Rok, pora roku, miesiąc... - leksyka temporalna w słownikach gwarowych Grodzieńszczyzny i jej literackie ekwiwalenty. Acta Baltico-Slavica, 35, pp. 109-129.

Šakun, Leǔ. (1984). Gistoryâ belaruskaj litaraturnaj movy. Minsk: Vydavectva Unìversìtèckae. [Шакун, Леў. (1984). Гісторыя беларускай літаратурнай мовы. Мінск: Выдавецтва Універсітэцкае].

Timoszuk, Mikołaj. (1990). O słownictwie Jakuba Kołasa. Studia z Filologii Rosyjskiej i Stowiańskiej, 13, pp. 249-256.

Vajtovìč, Nìna. (1958). Da pytannâ ab farmìravannì belaruskaj litaraturnaj movy. Minsk: Vydavectva Akadèmiì navuk BSSR. [Вайтовіч, Ніна. (1958). Да пытання аб фарміраванні беларускай літаратурнай мовы. Мінск: Выдавецтва Акадэміі Навук БССР]. 